\title{
35. DIAGENESIS OF ORGANIC COMPOUNDS IN HOLE 593, LEG 90 (TASMAN SEA) ${ }^{1}$
}

\author{
B. Mycke, K.-C. Emeis, and E. T. Degens, Geologisch-Paläontologisches Institut und Museum, \\ Universität Hamburg ${ }^{2}$
}

\begin{abstract}
$\mathrm{C}_{\mathrm{org}}$ and $\mathrm{N}_{\mathrm{org}}$ contents in the acid insoluble mineral fraction were studied in sediments of Site 593. Both decrease systematically from Recent to early Miocene over $425 \mathrm{~m}$ of carbonate facies. C/N ratios (7-11) are typically marine and indicate that residual organic matter, bound to clay minerals, was originally scavenged from the marine habitat rather than being of terrigenous origin. Variations of $\mathrm{C}_{\text {org }}$ and $\mathrm{N}_{\text {org }}$ are almost entirely controlled by rates of sedimentation, which gradually increase from Recent to early Miocene. Preliminary results of carbohydrate distribution indicate that epigenetic and diagenetic processes alter both the concentrations and the ratios of individual monomers with depth. Total carbohydrate concentrations in the samples diminish from $91 \mu \mathrm{g} / \mathrm{g}$ sediment at $18 \mathrm{~m}$ sub-bottom depth to $49 \mu \mathrm{g} / \mathrm{g}$ at $335 \mathrm{~m}$. In contrast, sugars in the acid insoluble residue increase with depth, suggesting release of structural polysaccharides and their subsequent association with clay minerals. Ratios of arabinose to fucose, which are about $6: 1$ in $\mathrm{Re}-$ cent carbonaceous sediments intercepted by sediment traps, vary from 1:1 in the youngest sample to $1: 2.5$ in the oldest.
\end{abstract}

\section{INTRODUCTION}

Amount and type of organic matter in deep-sea sediments is controlled by a series of factors, most notably: (1) primary production in the euphotic zone, (2) vertical and horizontal advection of particles, (3) rate of sedimentation, (4) burrowing activities, and (5) microbial degradation. Changes in any one of these variables will have an effect on $\mathrm{C}_{\text {org }}$ compounds.

Hole 593 from the Tasman Sea (southwest Pacific) exhibits a typical carbonate facies starved of clastic sediment input. This hole was analyzed for $\mathrm{C}_{\text {org }}, \mathrm{N}_{\text {org }}$, and carbohydrates $(\mathrm{CH})$ to discover the diagenetic fate of the organic matter. Emphasis was placed on organic matter associated with the acid insoluble fraction. Most of this organic matter is thought to be bound to clay minerals. Its point of origin could be terrestrial soils or the marine dissolved organic-carbon pool. In both instances organic matter was scavenged from an aqueous phase. It is of note that labile organic matter derived, for example, from calcified tissue was lost during the analytical operation.

Previous work has focused attention on the biogeochemistry of labile organic templates in foraminiferal tests and their rate of decay (Bada et al., 1978). Furthermore, variability in $\mathrm{C} / \mathrm{N}$ ratios as a measure of this decay has been discussed at length (e.g., Müller, 1977; Waples and Sloan, 1980; Müller and Suess, 1979). Because organic matter scavenged by clay minerals is rendered structurally more resistant, microbial degradation during early diagenesis should be minor. Because of its inertia, this type of organic matter is expected to survive diagenesis for an extended period of time.

\footnotetext{
${ }^{1}$ Kennett, J. P., von der Borch, C. C., et al., Init. Repts. DSDP, 90: Washington (U.S. Govt, Printing Office).

Address: Geologisch-Palăontologisches Institut und Museum, Universităt Hamburg, Bundesstrasse 55, D-2000 Hamburg 13, Federal Republic of Germany.
}

\section{METHODS}

Preparatory and analytical methods employed during this study are as follows. For the carbonate, ground and homogenized bulk samples were subjected to an acid treatment in a closed system $(0.1 \mathrm{~N}$ $\mathrm{H}_{3} \mathrm{PO}_{4}$ ). The amount of $\mathrm{CO}_{2}$ released was measured conductometrically by means of a Charmograph Model $6 \mathrm{CO}_{2}$ analyzer against reagent grade $\mathrm{CaCO}_{3}$ standards. For $\mathrm{C}_{\mathrm{org}}$ and $\mathrm{N}_{\mathrm{org}}$, ground and homogenized samples were acidified with $2 \mathrm{~N} \mathrm{HCl}$ and washed to neutrality with distilled water. Liquid was removed by centrifugation and was subsequently decanted. An aliquot of the vacuum-dried $\left(40^{\circ} \mathrm{C}\right)$ residue was combusted in an elemental analyzer (Carlo Erba Model 1104). For carbohydrates, following acid hydrolysis of ground bulk samples by $2 \mathrm{~N} \mathrm{HCl}$, individual monosaccharides were quantitatively analyzed by ion-exchange chromatography. Further details on analytical techniques are given elsewhere (Mopper, 1977).

\section{RESULTS}

Carbonate, $\mathrm{C}_{\text {org }}$, and $\mathrm{N}_{\text {org }}$ values are given in Table 1 and Figures 1 and 2. Except for two anomalous data points between 180 and $200 \mathrm{~m}$ sub-bottom depth, there is a general decrease (with wide scatter) in $\mathrm{C}_{\text {org }}$ to a depth of $475 \mathrm{~m}$ in Hole 593. The increase in organic carbon below $475 \mathrm{~m}$ coincides with an unconformity (lower Miocene/lower Pliocene). $\mathrm{C}_{\text {org }}$ values of the carbonate-free residue generally range from 0.2 to $1.2 \%$, whereas the corresponding $\mathrm{N}_{\text {org }}$ values are an order of magnitude lower at $\sim 0.02$ to $0.1 \%$. The resulting $\mathrm{C} / \mathrm{N}$ ratios fall mostly in the range from 7 to 11 and thus correspond to ratios commonly found in marine sediments (e.g., Emery and Rittenberg, 1952; Degens, 1970; Müller and Suess, 1979) and in the dissolved marine organic-carbon pool (Holm-Hansen et al., 1966; Degens and Ittekkot, 1983).

In contrast, $\mathrm{C} / \mathrm{N}$ ratios in terrestrial humic compounds of soil and riverine provenance are considerably higher (15-40). Some of the scattering of $\mathrm{C} / \mathrm{N}$ ratios in our samples can be attributed to the low $\mathrm{N}_{\text {org }}$ contents in a number of samples just barely above the detection limit. The reported increase in $\mathrm{C} / \mathrm{N}$ ratios with depth for pelagic sediments (e.g., Trask and Patnode, 1942; Waples and Sloan, 1980) could not be corroborated by our data set. 
Table 1. Organic matter data for Hole 593.

\begin{tabular}{|c|c|c|c|c|c|c|}
\hline $\begin{array}{l}\text { Depth } \\
(\mathrm{m})\end{array}$ & $\begin{array}{c}\mathrm{CaCO}_{3} \\
(\%)\end{array}$ & $\underset{(\%)}{C_{\min }}$ & $\begin{array}{l}\text { Corg } \\
(\%)^{a}\end{array}$ & $\begin{array}{l}\text { Norg } \\
(\%)^{a}\end{array}$ & $\mathrm{C} / \mathrm{N}^{\mathrm{a}}$ & $\begin{array}{l}\text { Total } \\
\mathrm{C}_{\text {org }} \\
(\%)^{\mathrm{b}}\end{array}$ \\
\hline 3.6 & 85.1 & 10.1 & 0.50 & 0.06 & 8.3 & 0.07 \\
\hline 8.7 & 89.7 & 10.6 & 0.99 & 0.13 & 7.6 & 0.10 \\
\hline 18.3 & 83.8 & 9.9 & 0.85 & 0.06 & 14.2 & 0.14 \\
\hline 27.5 & 89.0 & 10.5 & 0.71 & 0.07 & 10.1 & 0.08 \\
\hline 47.1 & 91.2 & 10.8 & 0.63 & 0.06 & 10.5 & 0.06 \\
\hline 56.7 & 92.4 & 10.9 & 0.40 & 0.06 & 6.7 & 0.05 \\
\hline 75.9 & 92.1 & 10.9 & 0.50 & 0.05 & 10.2 & 0.04 \\
\hline 95.1 & 94.0 & 11.1 & 0.86 & 0.06 & 14.3 & 0.05 \\
\hline 114.3 & 95.9 & 11.4 & 0.67 & 0.05 & 13.4 & 0.03 \\
\hline 123.9 & nd & nd & 1.03 & 0.09 & 11.4 & nd \\
\hline 133.5 & 95.7 & 11.3 & 0.92 & 0.06 & 15.3 & 0.04 \\
\hline 143.1 & 96.8 & 11.5 & 0.93 & 0.03 & 31.0 & 0.03 \\
\hline 152.7 & 94.9 & 11.2 & 0.57 & 0.05 & 11.4 & 0.03 \\
\hline 162.3 & 95.2 & 11.3 & 0.63 & 0.04 & 15.7 & 0.03 \\
\hline 171.9 & 94.8 & 11.3 & 0.59 & 0.05 & 11.8 & 0.03 \\
\hline 181.5 & 96.0 & 11.4 & 1.66 & 0.09 & 18.4 & 0.07 \\
\hline 191.1 & nd & nd & 1.42 & 0.10 & 14.2 & nd \\
\hline 210.3 & 95.9 & 11.5 & 0.62 & 0.03 & 20.7 & 0.03 \\
\hline 219.9 & 95.1 & 11.3 & 0.45 & 0.06 & 7.5 & 0.02 \\
\hline 229.5 & 93.6 & 11.1 & 0.64 & 0.08 & 8.0 & 0.04 \\
\hline 239.1 & 95.2 & 11.3 & 0.35 & 0.06 & 5.8 & 0.02 \\
\hline 258.3 & 91.9 & 10.9 & 0.67 & 0.07 & 9.6 & 0.05 \\
\hline 267.9 & 94.0 & 11.2 & 0.67 & 0.05 & 13.4 & 0.04 \\
\hline 277.5 & 97.0 & 11.5 & 0.41 & 0.04 & 10.3 & 0.01 \\
\hline 287.1 & 95.2 & 11.3 & 0.68 & 0.04 & 17.0 & 0.03 \\
\hline 296.7 & 93.3 & 11.1 & 0.41 & 0.03 & 13.7 & 0.0 \\
\hline 306.3 & 96.1 & 11.4 & 0.73 & 0.02 & 36.5 & 0. \\
\hline 315.9 & 91.0 & 10.8 & 0.73 & 0.09 & 8.1 & 0.0 \\
\hline 325.5 & 94.3 & 11.2 & 0.34 & 0.01 & 48.6 & 0.0 \\
\hline 335.1 & 93.1 & 11.1 & 0.53 & 0.03 & 17.7 & 0.0 \\
\hline 344.7 & 92.6 & 11.0 & 0.35 & 0.03 & 11.7 & 0.0 \\
\hline 354.3 & 90.5 & 10.8 & 0.51 & 0.06 & 8.5 & 0.0 \\
\hline 363.9 & 93.4 & 11.1 & 0.31 & 0.04 & 7.8 & 0.0 \\
\hline 373.5 & 92.8 & 11.0 & 0.40 & 0.05 & 8.0 & 0.03 \\
\hline 383.1 & 93 & 11.2 & 0.40 & 0.05 & 8.0 & 0 \\
\hline 392.7 & .0 & 10.9 & 0.45 & 0.07 & 6.4 & 0.0 \\
\hline 402.3 & & & 0.30 & 0.04 & 7.5 & 0 \\
\hline 421.5 & 92.8 & 11.0 & 0.36 & 0.04 & 9.0 & 0.03 \\
\hline 431.1 & & 11.2 & 0.27 & 0.04 & 6.8 & 0.02 \\
\hline 450.3 & 95.3 & 11.3 & 0.23 & 0.03 & 7.7 & 0.0 \\
\hline 469.5 & & & 0.29 & 0.04 & 7.3 & 0.0 \\
\hline 488.7 & 95.5 & 11.4 & 0.93 & 0.08 & 11.6 & 0.0 \\
\hline 498.3 & & & 0.88 & 0.07 & 12.6 & \\
\hline 507.9 & 96.4 & 11.5 & 0.56 & 0.06 & 9.3 & 0.02 \\
\hline 517.5 & & 11.3 & 0.76 & 0.06 & 12.7 & 0.03 \\
\hline 565.5 & 90.6 & 10.8 & 1.09 & 0.18 & 6.1 & 0.06 \\
\hline
\end{tabular}

Note: nd $=$ no data.

a In acid insoluble residue.

b Percentage of acid insoluble $\mathrm{C}_{\mathrm{org}}$ computed for bulk sample.

\section{DISCUSSION}

\section{Organic Carbon and Nitrogen}

The decrease of $\mathrm{C}_{\mathrm{org}}$ in the residue fraction of Hole 593 is substantiated by the calculation of a regression analysis. Including or excluding the two data points at 181.5 and $191.1 \mathrm{~m}$ does not significantly change the slope of regression $\left(-1.0 \times 10^{-3}\right.$ versus $\left.-1.1 \times 10^{-3}\right)$. The higher $\mathrm{C}_{\text {org }}$ values in lower Oligocene sediments were excluded in this calculation, because they belong to a different sedimentation regime.

Eq. (1) describes $\mathrm{C}_{\text {org }}$ loss with depth:

$$
x_{\mathrm{C}}=\left(-1.0 \times 10^{-3}\right) y_{\mathrm{d}}+0.8
$$

where $x_{\mathrm{C}}$ is $\mathrm{C}_{\text {org }}$ loss (\%) with depth and $y_{\mathrm{d}}$ is sub-bottom depth (m).

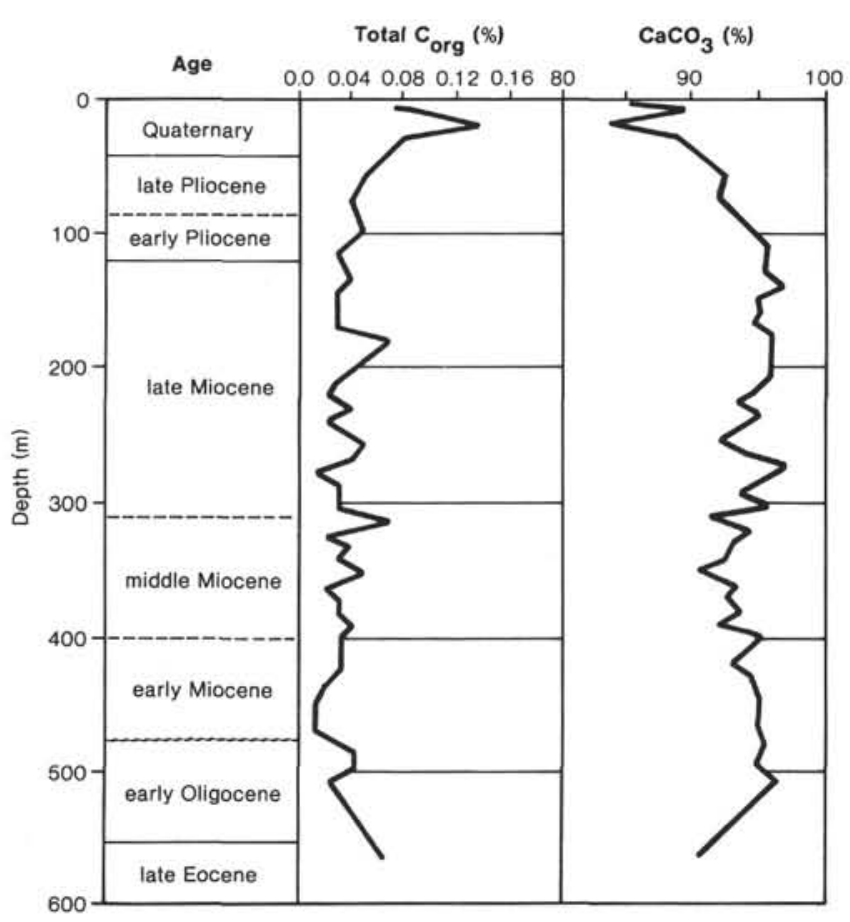

Figure 1. Plot of carbonate $\left(\mathrm{CaCO}_{3}\right)$ content and computed total $\mathrm{C}_{\text {org }}$ through time for Hole 593.

A plot of $\mathrm{C}_{\text {org }}$ decrease versus time allows the estimation of diagenetic $\mathrm{C}_{\mathrm{org}}$ loss in the noncarbonate residue of calcareous sediments. For this purpose, five geological time markers in Hole 593 were selected. $\mathrm{C}_{\text {org }}$ concentrations at their respective depths were calculated according to Eq. (1) leading to Eq. (2), which describes $\mathrm{C}_{\text {org }}$ loss with time:

$$
x_{\mathrm{C}}=\left(-3.0 \times 10^{-2}\right) y_{\mathrm{t}}+0.82
$$

where $y_{\mathrm{t}}$ is time duration (m.y.). The rate constant for the $\mathrm{C}_{\mathrm{org}}$ loss of the residual fraction can thus be inferred by the slope of Eq. (2).

The following conclusions can be reached. A total of $0.03 \% \mathrm{C}_{\text {org }}$ contained in the acid insoluble residue is consumed every $1 \mathrm{~m} . \mathrm{y} . \mathrm{C}_{\text {org }}$ gradually decreases from $0.82 \%$ at the top of the hole to $0.4 \%$ at a depth of $475 \mathrm{~m}$, i.e., from Recent to early Miocene (Fig. 3). Comparable calculations by Waples and Sloan (1980) indicate total diagenetic loss of $\mathrm{C}_{\text {org }}$ at a depth of about $100 \mathrm{~m}$, which coincides with the Pliocene/Pleistocene boundary. Below this interface they observed constant $\mathrm{C}_{\text {org }}$ values.

The same calculations were performed for $\mathrm{N}_{\text {org }}$. Loss of $\mathrm{N}_{\text {org }}$ with depth follows the $\mathrm{C}_{\text {org }}$ pattern, but with a different slope:

$$
x_{\mathrm{N}}=\left(-7.07 \times 10^{-5}\right) y_{\mathrm{d}}+0.07
$$

The depletion of residual nitrogen is also a simple time-dependent process, as can be deduced from the highly significant correlation $(r=0.9998)$ between the calculated decrease with depth and time. Calculation of the regression for $\mathrm{N}_{\text {org }}$ content versus time yields Eq. (4). 


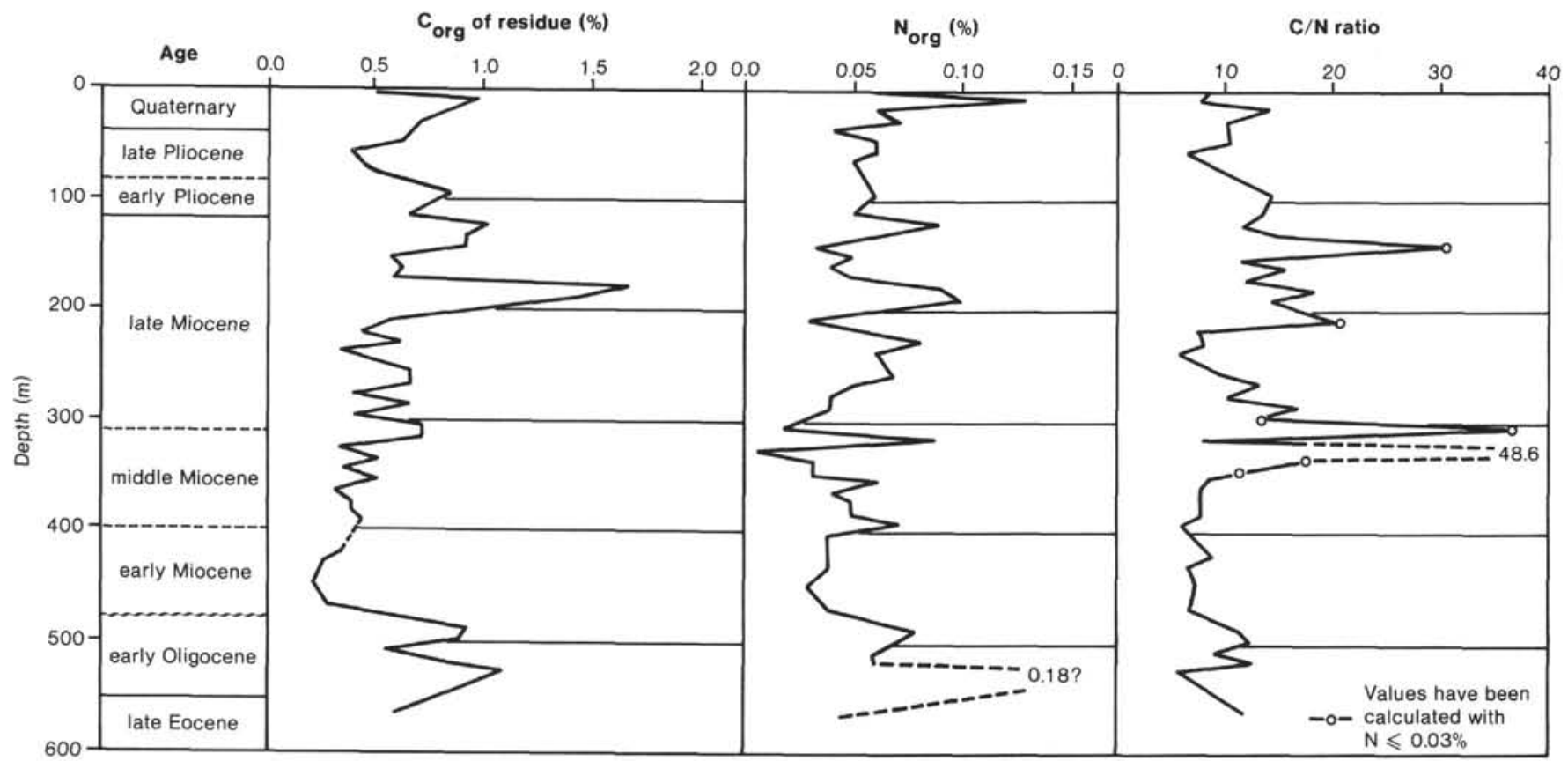

Figure 2. Plot of $\mathrm{C}_{\text {org }}, \mathrm{N}_{\text {org }}$, and $\mathrm{C} / \mathrm{N}$ ratios.

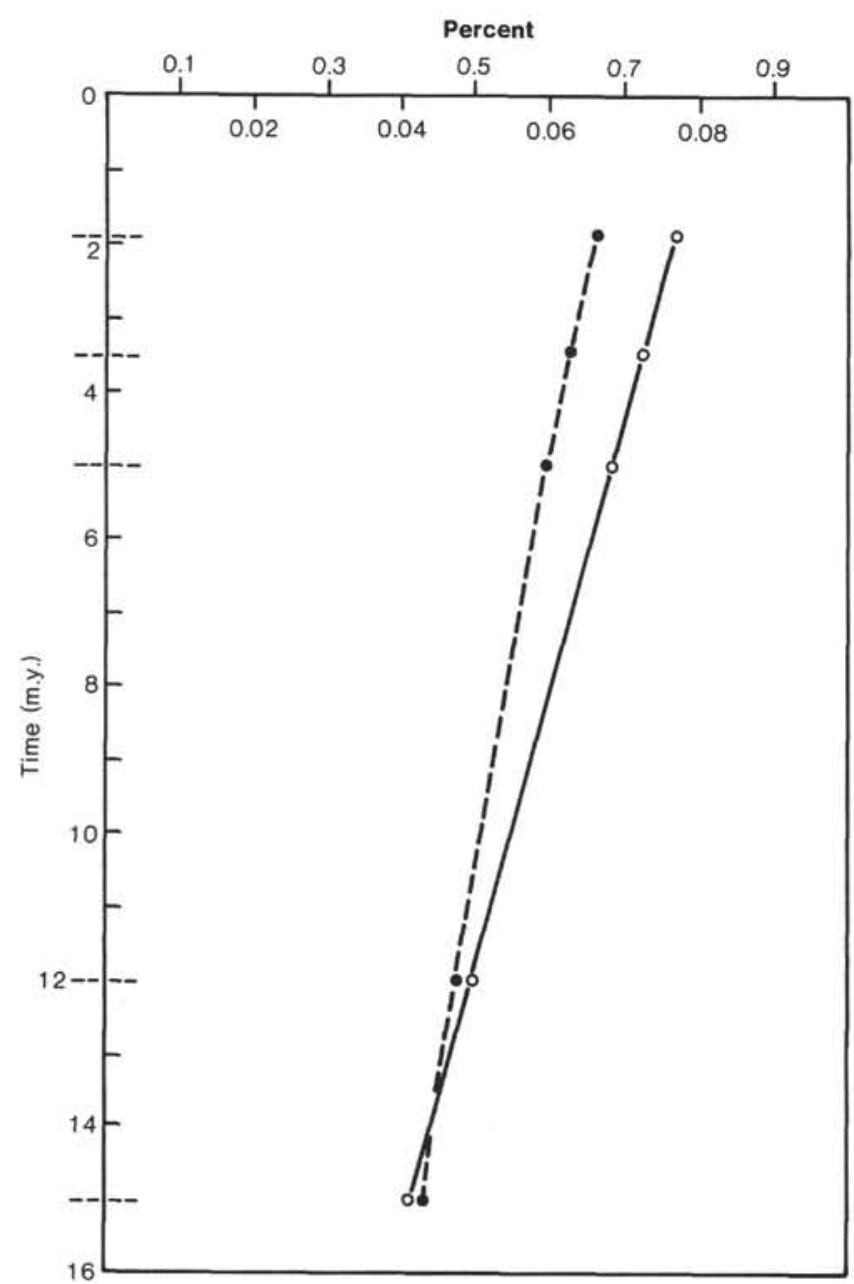

Figure 3. Regression analysis plot of $\mathrm{C}_{\text {org }}$ (solid line) and $\mathrm{N}_{\text {org }}$ (dashed line) in residue through time.

$$
x_{\mathrm{N}}=\left(-1.9 \times 10^{-3}\right) y_{\mathrm{t}}+0.07
$$

These findings are consistent with those of Waples and Sloan (1980) who described the loss of $\mathrm{N}_{\text {org }}$ as a continuous process, although their decrease follows first-order kinetics. An explanation for this can be found in the source of nitrogenous matter in deep-sea sediments. A major part of $\mathrm{N}_{\text {org }}$ delivered to the ocean floor stems from proteinaceous matter in tests of planktonic organisms (Ittekkot, Degens et al., 1984; Ittekkot, Deuser et al., 1984).

The diagenetic fate of such proteinaceous templates in foraminiferal tests has been studied by Bada et al. (1978). They reached the conclusion that amino acid decomposition follows first-order kinetics and comes to completion within $1 \mathrm{~m}$.y. Because we removed the labile or acid hydrolyzable $\mathrm{N}_{\text {org }}$ fraction, the depth distribution of residual $\mathrm{N}_{\text {org }}$ can be used to reinterpret the data set of Waples and Sloan (1980) and Bada et al. (1978). Namely, their observed exponential decrease of $\mathrm{N}_{\text {org }}$ is simply a reflection of the decomposition rate of labile $\mathrm{N}_{\text {org }}$ compounds, but not of total $\mathrm{N}_{\text {org }}$ :

$$
\mathrm{N}_{\text {org(total) }}=\mathrm{N}_{\text {org(labile) }}+\mathrm{N}_{\text {org(residual) }}
$$

The different slopes for $\mathrm{C}_{\text {org }}$ and $\mathrm{N}_{\text {org }}$ loss mirror decreasing $\mathrm{C} / \mathrm{N}$ ratios with depth (Table 1 and Figs. 2 and 3). Müller (1977) explains this relationship by sorption of nitrogeneous compounds to clay minerals. Although his inferences were drawn only from a study of a $5-\mathrm{m}$ core section, they appear to be applicable also for the 475-m core section of Hole 593. It should be noted that the residual fraction of that core, measuring about 5 to $15 \%$, is predominantly clay.

The simultaneous (but not parallel) decrease of $C_{\text {org }}$ and $\mathrm{N}_{\text {org }}$ with depth could be explained by changes in 
the rate of sedimentation. This would correspond to the interpretation offered by Müller and Suess (1979) for a similar situation. In the present case this would indicate a decrease in the rate of deposition since middle Miocene. Because the ratio of carbonate to residue is about the same for the whole length of the core below $100 \mathrm{~m}$, contributions from primary production and terrigenous matter have apparently decreased proportionally.

This observation is in agreement with recent findings on the biological control of the removal of clay-sized detritus from the water column (Deuser et al., 1983; Honjo, 1980; Ittekkot, Degens et al., 1984; Ittekkot, Deuser et al., 1984; Degens et al., 1984). The decreasing trend in the rate of sedimentation becomes even more obvious by considering compaction effects. Einsele (1977) has shown that the porosity of a chalk ooze decreases exponentially to a depth of $200 \mathrm{~m}$. Because the facies of sediments recovered from Hole 593 is identical to that of sediments studied by Einsele (1977), sedimentation rates given in Table 2 for the Pliocene-Quaternary section could be in error by as much as $20 \%$. The validity of our calculation and its inherent error can be appreciated when it is compared to calculations of sedimentation rates based on mass accumulation rate data presented in Kennett (this vol.). These revised sedimentation rates based on his data, which are also given in Table 2, do not significantly alter the trend observed in our model.

In summary, the $\mathrm{C}_{\mathrm{org}}$ and $\mathrm{N}_{\text {org }}$ relationships in the residual fraction of Hole 593 suggest the following conclusions. (1) $\mathrm{C}_{\mathrm{org}}$ and $\mathrm{N}_{\mathrm{org}}$ originated in the marine habitat and were extracted from the dissolved organic-matter pool or from aqueous solutions in the "benthic layer" or topmost sediment; (2) the low $\mathrm{C} / \mathrm{N}$ ratios argue against terrestrial sources; (3) the geothermal gradient is too low to significantly alter $\mathrm{C} / \mathrm{N}$ ratios or to introduce catagenesis of organic matter; (4) changes in $\mathrm{C}_{\text {org }}$ and $\mathrm{N}_{\mathrm{org}}$ content are principally related to changes in the rate of deposition; and (5) the systematic decrease in $\mathrm{C}_{\text {org }}$ and $\mathrm{N}_{\text {org }}$ with depth implies that rates of deposition have decreased from middle Miocene to Recent.

\section{Carbohydrates}

Preliminary data on the carbohydrate $(\mathrm{CH})$ content of bulk carbonates (Hole 593) and of the carbonate-free residue are summarized in Table 3 . Total $\mathrm{CH}$ content is low because of low $\mathrm{C}_{\text {org }}$ values. A decrease with depth is indicated, and some sugars are more affected than others (Fig. 4). The relative abundances of mannose, galac-

Table 2. Estimated sedimentation rates in Hole 593.

\begin{tabular}{cclccc}
\hline & & & & \multicolumn{2}{c}{$\begin{array}{c}\text { Sedimentation rate } \\
(\mathrm{m} / \mathrm{m} . \mathrm{y} .)\end{array}$} \\
\cline { 4 - 5 } $\begin{array}{c}\text { Thickness } \\
(\mathrm{m})\end{array}$ & $\begin{array}{c}\text { Deposition } \\
\text { time span } \\
(\mathrm{m} . \mathrm{y} .)^{\mathrm{a}}\end{array}$ & & Age & Uncorrected & MAR $^{\mathrm{c}}$ \\
\hline 38 & 1.9 & Quaternary & 20.0 & 23.3 \\
44 & 1.6 & late Pliocene & 27.7 & 16.7 \\
38 & 1.5 & early Pliocene & 25.3 & 33.3 \\
190 & 7.0 & late Miocene & 27.1 & 26.7 \\
90 & 3.0 & middle Miocene & 30.0 & 33.3 \\
\hline
\end{tabular}

a After Van Eysinga (1975).

${ }^{b}$ Calculated without correction for compaction of the sediment.

c Calculated from mass accumulation rates (MAR); site chapter (this vol.).
Table 3A. Carbohydrates in Hole 593: Total sugars $(\mu \mathrm{g} / \mathrm{g}$ sediment).

\begin{tabular}{lrrrr}
\hline & \multicolumn{4}{c}{ Sub-bottom depth (m) } \\
\multicolumn{1}{c}{ Sugar } & 18.3 & 133.5 & \multicolumn{1}{c}{229.5} & \multicolumn{1}{c}{335.1} \\
\hline Mannose & 3.64 & 1.96 & 1.58 & nd \\
Fructose & 31.97 & 27.35 & 22.01 & 21.21 \\
Arabinose & 7.87 & 6.69 & 2.99 & 3.46 \\
Fucose & 9.36 & 8.49 & 8.54 & 9.88 \\
Galactose & 7.74 & 2.63 & 1.14 & 0.68 \\
Xylose & 6.39 & 3.10 & 0.55 & 0.43 \\
Glucose & $\underline{24.4}$ & $\underline{25.86}$ & $\underline{20.81}$ & 13.37 \\
Total sugars & $\mathbf{9 1 . 3 7}$ & $\mathbf{7 6 . 0 9}$ & $\mathbf{5 7 . 9 0}$ & $\underline{49.03}$ \\
\hline
\end{tabular}

Table 3B. Carbohydrates in Hole 593: Sugars in residue ( $\mu \mathrm{g} / \mathrm{g}$ residue).

\begin{tabular}{|c|c|c|c|}
\hline \multirow[b]{2}{*}{ Sugar } & \multicolumn{3}{|c|}{ Sub-bottom depth (m) } \\
\hline & 37.5 & 56.7 & 191.1 \\
\hline Rhamnose & 12.42 & 12.56 & 43.53 \\
\hline Mannose & 15.19 & 58.93 & 138.16 \\
\hline Fructose & 11.44 & 37.29 & 133.5 \\
\hline Arabinose & 23.91 & 37.63 & 101.87 \\
\hline Fucose & 11.45 & 16.99 & 86.32 \\
\hline Galactose & 30.82 & 48.36 & 90.90 \\
\hline Xylose & 18.91 & 116.51 & 282.62 \\
\hline Glucose & 32.29 & 168.88 & 575.76 \\
\hline Total sugars & 156.43 & 497.15 & 1452.67 \\
\hline
\end{tabular}

tose, and xylose decrease, resulting in a predominance of fructose and glucose in deeper samples. The ratio or arabinose to fucose has been used to distinguish periods of dominantly calcareous input from periods of opaline biogenic input in sediment trap experiments (Ittekkot, Degens et al., 1984; Ittekkot, Deuser et al., 1984). They report a ratio of about $6: 1$ in purely carbonaceous trap material.

Although sediments in Hole 593 are very pure biogenic chalks, the arabinose to fucose ratio decreases from $1: 1$ in surface samples to $1: 2.5$ in the deepest sample, suggesting mechanisms at the water/sediment interface that invert this ratio (Table $3 \mathrm{~A}$ ). In addition, the relative enrichment of fucose with depth is indicative of selective removal of other $\mathrm{CH}$ during diagenesis. The $\mathrm{CH}$ fraction in residual material, after removal of biogenic carbonates and associated $\mathrm{CH}$, consists predominantly of glucose and xylose. The increase of these sugars with depth (Table 3B) is notable and is tentatively explained by diagenetic release of structural polysaccharides during recrystallization. The polysaccharides then associate with clay minerals.

\section{ACKNOWLEDGMENT}

Financial support was given by the Deutsche Forschungsgemeinschaft, Bonn-Bad Godesberg. Laboratory assistance of M. Sternhagen is gratefully acknowledged.

\section{REFERENCES}

Bada, J. L., Shou, M.-J., Manx, E. H., and Schroeder, R. A., 1978. Decomposition of hydroxy amino acids in foraminiferal tests: Kinetics mechanism and geochronological implications. Earth Planet. Sci. Lett., 41:67-76.

Degens, E. T., 1970. Molecular nature of nitrogenous compounds in sea water and recent marine sediments. In Wood, D. W. (Ed.), Or- 
ganic Matter in Natural Waters. Institute of Marine Sciences, Alaska, 1:77-106.

Degens, E. T., and Ittekkot, V., 1983. A new look at clay-organic interactions. In Degens, E. T., Krumbein, W. E., and Prashnowsky, A. A. (Eds.), Ein Norg-Süd Profil: Zentraleuropa-MittelmeerraumAfrika. Mitt. Geol.-Paläont. Inst. Univ. Hamburg, Festband Georg Knetsch, 56:229-248.

Degens, E. T., Kempe, S., and Spitzy, A., 1984. $\mathrm{CO}_{2}$ : A biogeochemical portrayal. In Hutzinger, O. (Ed.), Handbook of Environmental Chemistry, (Vol. I/C): Berlin (Springer-Verlag), pp. 127-215.

Deuser, W. G., Brewer, P. G., Jickells, T. D., and Commeau, R. D., 1983. Biological control of the removal of abiogenic particles from the surface ocean. Science (Washington, D.C.), 219:388-391.

Einsele, G., 1977. Range, velocity, and material flux of compaction flow in growing sedimentary sequences. Sedimentology. 24:639-655.

Emery, K. O., and Rittenberg, S. C., 1952. Early diagenesis of California Basin sediments in relation to origin of oil. Am. Assoc. Pet. Geol. Bull., 36:735-806.

Hecky, E., Mopper, K., Kilham, P., and Degens, E. T., 1973. The amino acid and sugar composition of diatom cell walls. Mar. Biol., 19:323-331.

Holm-Hansen, O., Strickland, J. D. H., and Williams, P. M., 1966. A detailed analysis of biologically important substances in a profile off Southern California. Limnol. Oceanogr., 11:548-561.

Honjo, S., 1980. Material fluxes and modes of sedimentation in the mesopelagic and bathypelagic zones. J. Mar. Res., 38:53-97.
Ittekkot, V., Degens, E. T., and Honjo, S., 1984. Seasonality in the fluxes of sugars, amino acids, and amino sugars to the deep ocean: Panama Basin. Deep-Sea Res., 31/9A:1071-1083.

Ittekkot, V., Deuser, W. G., and Degens, E. T., 1984. Seasonality in the fluxes of sugars, amino acids, and amino sugars to the deep ocean: Sargasso Sea. Deep-Sea Res., 31/9A:1057-1069.

Mopper, K., 1977. Sugars and uronic acids in sediments and water from Black Sea and North Sea with emphasis on analytical techniques. Mar. Chem., 5:585-603.

Müller, P. J., 1977. C/N ratios in Pacific deep sea sediments: Effect of inorganic ammonium and organic nitrogen compounds sorbed by clays. Geochim. Cosmochim. Acta, 41:765-776.

Müller, P. J., and Suess, E., 1979. Productivity, sedimentation rate, and sedimentary organic matter in the oceans, I: Organic carbon preservation. Deep-Sea Res., 26A:1347-1362.

Trask, P. D., and Patnode, H. W., 1942. Source Beds of Petroleum: Tulsa (Am. Assoc. Pet. Geol. Memoir).

Van Eysinga, F. W. B., 1975. Geological Time Table. Amsterdam (Elsevier).

Waples, D. W., and Sloan, J. R., 1980. Carbon and nitrogen diagenesis in deep sea sediments. Geochim. Cosmochim. Acta, 44: 1463-1470.

Date of Initial Receipt: 2 January 1985 Date of Acceptance: 15 April 1985

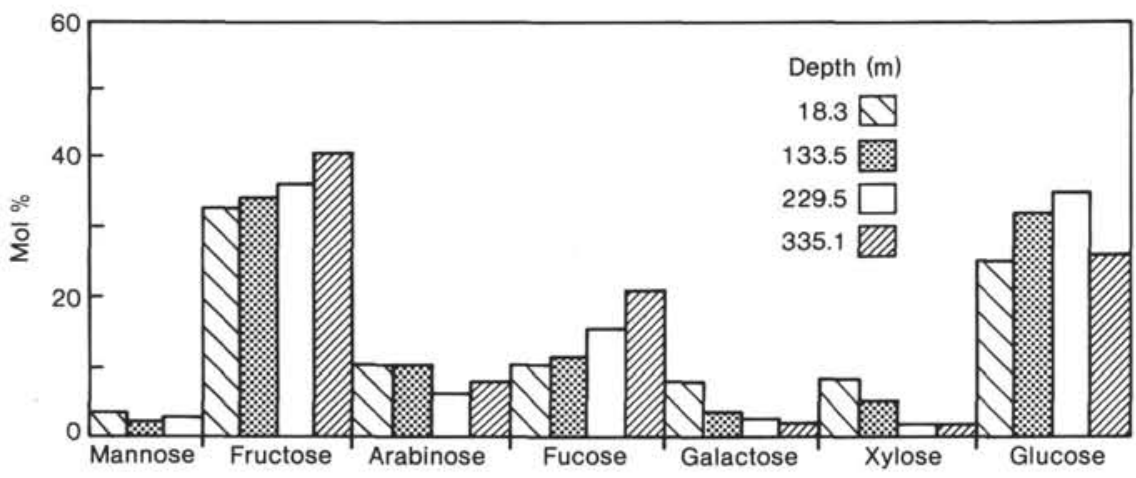

Figure 4. Amount of acid hydrolyzable sugars with depth in bulk samples from Hole 593. 